\title{
Extracellular Vesicles: A Therapeutic Option for Liver Fibrosis
}

\author{
Stefania Bruno *(D), Giulia Chiabotto ${ }^{D}$ and Giovanni Camussi $(\mathbb{D}$ \\ Department of Medical Sciences and Molecular Biotechnology Center, University of Torino, 10126 Torino, Italy; \\ giulia.chiabotto@unito.it (G.C.); giovanni.camussi@unito.it (G.C.) \\ * Correspondence: stefania.bruno@unito.it
}

Received: 27 April 2020; Accepted: 11 June 2020; Published: 15 June 2020

\begin{abstract}
Extracellular vesicles (EVs) are a heterogeneous population of small membrane vesicles released by all types of cells in both physiological and pathological conditions. EVs shuttle different types of molecules and are able to modify the behavior of target cells by various mechanisms of action. In this review, we have summarized the papers present in the literature, to our acknowledge, that reported the EV effects on liver diseases. EVs purified from serum, stem cells, and hepatocytes were investigated in different experimental in vivo models of liver injury and in particular of liver fibrosis. Despite the different EV origin and the different types of injury (toxic, ischemic, diet induced, and so on), EVs showed an anti-fibrotic effect. In particular, EVs had the capacities to inhibit activation of hepatic stellate cells, one of the major players of liver fibrosis development; to reduce inflammation and apoptosis; to counteract the oxidative stress; and to increase hepatocyte proliferation, contributing to reducing fibrosis and ameliorating liver function and morphology.
\end{abstract}

Keywords: exosomes; stem cells; collagen deposition; inflammation; acute liver injury; chronic liver damage

\section{Introduction}

Different types of injury (ischemic, toxic, oxidative stress, and so on) may induce acute liver damage, which can elicit tissue inflammation. Inflammation, in turn, may contribute to further injury. When the injury or the inflammation persists, liver fibrosis may develop, eventually leading to end-stage liver disease, cirrhosis, and hepatocellular carcinoma. Although liver transplantation is the standard therapy for end-stage liver disease, its use is limited by insufficient availability of organs as well as by medical (immunosuppressive therapies) and financial considerations. To establish new anti-fibrotic and anti-inflammatory therapeutic strategies is one of the major clinical options to avoid transplantation. Preclinical studies have suggested that stem cells and their bio-products, in particular stem cell-derived extracellular vesicles (EVs), may represent a therapeutic option to treat or to alleviate liver fibrosis and inflammation.

\section{Classification and Biogenesis of EVs}

The term "EVs" was proposed in 2011 [1] to indicate vesicles enclosed by a lipid bilayer membrane and secreted into the extracellular space by virtually all cells in both physiological and pathological conditions. Therefore, EVs can be found in all biological fluids.

To date, the classification of EVs depends on their biogenesis, molecular composition, size, and density, and includes three main categories: exosomes, microvesicles, and apoptotic bodies [2,3]. Exosomes are small vesicles with an estimated size that ranges between 30 and $120 \mathrm{~nm}$ in diameter. They derive from intracellular trafficking through the endolysosomal pathway and their release is controlled by several cellular processes, including ceramide synthesis and calcium signaling [4]. 
Microvesicles (MVs), also known as microparticles or ectosomes, arise directly from the plasma membrane and range usually from 100 to $1000 \mathrm{~nm}$ in diameter. Whereas pre-apoptotic EVs have a larger size, those released from perfectly normal cells have a nano range size that may prevent size-dependent distinction from exosomes and are preferentially called ectosomes [5]. Lastly, apoptotic bodies are vesicles with a diameter of $1000-5000 \mathrm{~nm}$. Apoptotic bodies arise from plasma membrane blebbing during apoptosis and represent fragments of dead cells [6]. These three EV categories are extremely heterogeneous in size and molecular content. Moreover, EVs isolated on the basis of their size have been shown to express several common protein markers [7] and a specific marker to distinguish one type of vesicle from another is still lacking. Finally, EV heterogeneity is increased by the lack of standardization in the isolation procedures, which include differential ultracentrifugation, density gradient separation, immunoaffinity purification, and size-exclusion chromatography [8]. Exosomes' biogenesis begins with the generation of intraluminal vesicles (ILVs) from the inward and reverse membrane budding of intracellular endosomal structures, known as multivesicular bodies (MVBs). After fusion of MVBs with the cell surface, the ILVs contained within their lumen are released into the extracellular space, generating the exosomes [9] (Figure 1).

The endosomal sorting complex required for transport (ESCRT) machinery contributes to ILVs' generation by controlling the selection of cargo (ESCRT-0), the intraluminal membrane budding (ESCRT-I and -II), and the membrane fission (ESCRT-III) [10-12]. The ESCRT complexes act in coordination with associated proteins required for exosome formation and secretion, such as hepatocyte growth factor-regulated tyrosine kinase substrate (HRS) [13,14], tumor susceptibility gene 101 protein (TSG101) [14], apoptosis-linked gene-2 interacting protein X (ALIX) [15], and vacuolar protein sorting-associated protein 4 (VPS4) [16]. However, exosome biogenesis can also occur in the absence of the ESCRT protein machinery [17]. An important role in exosome formation is played by tetraspanins (e.g., CD63, CD81, and CD9), transmembrane proteins particularly enriched in EVs [18-21]. Tetraspanins are mainly implicated in specific cargo sorting into ILVs [21-24] and in exosome release [25]. A lipid-driven mechanism has been also demonstrated [26]. In particular, exosome biogenesis may depend on ceramide synthesis, as the inhibition of neutral sphingomyelinase 2 , an enzyme that converts sphingomyelin into ceramide, has proved to reduce exosome release $[27,28]$. Exosome secretion can be controlled by calcium. Treatment with calcium ionophores results in enhanced intracellular calcium levels, which prompt the exosome secretion [29,30]. Rearrangements in the actin and microtubule cytoskeleton also contribute to the transport of MVBs to the plasma membrane [31-33]. Among all proteins involved in exosome secretion, small guanosine triphosphatase (GTPase) RhoA [34], Ral-1 [35], and soluble N-ethylmaleimide-sensitive factor attachment protein receptors (SNAREs) [36,37] are required for MVB fusion with the plasma membrane. A growing body of research has focused on Rab GTPases involved in regulation of EV budding, transport along the cytoskeleton, and membrane fusion [38,39]. Examples of Rab GTPases associated with the exosome release are Rab11 [40], Rab27a [31,41,42], Rab27b [41], and Rab35 [43]. Despite being a different process from exosome formation, MV generation still involves the endosomal machinery, including several components of the ESCRT system, such as TSG101 and VPS4 [44]. Tetraspanins are also found in MVs, though less is known about their role in MV biogenesis [20]. MVs originate from the direct outward budding of the cell membrane [45] (Figure 1). In this process, several molecular modifications within the plasma membrane may occur, including changes in protein composition, rearrangements in lipid asymmetry and components, and a rise in calcium levels [45,46]. It has been demonstrated that the interaction between TSG101 and the arrestin domain-containing protein-1 (ARRDC1) causes the shift in TSG101 localization from endosomal membranes to the plasma membrane, thus resulting in membrane bending [45]. Moreover, the exposition of phosphatidylserine from the inner leaflet to the cell surface requires calcium-dependent enzymatic machineries, such as aminophospholipid translocases (flippases and floppases), scramblases, and calpain, which all contribute to the membrane bending process [47]. Like the exosome generation, MV biogenesis also requires the contribution of cytoskeletal proteins and their regulators. In particular, the Rho family of small GTPases and the Rho-associated protein 
kinase (ROCK) participate in MV generation by regulating actin dynamics [48]. A key regulator of MV shedding is the Ras-related GTPase ADP-ribosylation factor 6 (ARF6) [49]. Together with ARF1, ARF6 is involved in actin remodeling, cell invasion, and endocytic trafficking [50,51]. Their activation leads to the phosphorylation of myosin light chain and actomyosin contraction, thus resulting in the fission of MVs from the cell membrane $[49,52]$.



Figure 1. Extracellular vesicle (EV) biogenesis and secretion. Schematic representation of the formation and release of exosomes and microvesicles (MVs) by eukaryotic cells. Exosomes arise from intraluminal vesicles (ILVs) by budding into early endosomes and multivesicular bodies (MVBs). Several molecules are involved in ILV formation, in particular, lipids (e.g., ceramide) and proteins like tetraspanins (e.g., CD63, CD81, and CD9) and the endosomal sorting complex required for transport (ESCRT) machinery with its associated factors hepatocyte growth factor-regulated tyrosine kinase substrate (HRS), tumor susceptibility gene 101 protein (TSG101), apoptosis-linked gene-2 interacting protein X (ALIX), and vacuolar protein sorting-associated protein 4 (VPS4). Several Rab small guanosine triphosphatases (GTPases) (e.g., Rab11, Rab27a/b, and Rab35) contribute to transportation of MVBs to the plasma membrane, thus eliciting the exosome secretion. Other proteins involved in MVB fusion with the plasma membrane are Rho-A, Ral-1, and soluble N-ethylmaleimide-sensitive factor attachment protein receptors (SNAREs). Many of these proteins also participate in MV biogenesis, such as TSG101 through the interaction with arrestin domain-containing protein-1 (ARRDC1). Proteins associated to the Rho (ROCK) and the Ras GTPase family (ARF1, ARF6) also contribute to MV generation by controlling cytoskeleton rearrangements. Furthermore, a rise in calcium intracellular levels contributes to EV secretion. The molecular content of exosomes is also represented.

In the last decades, EVs have emerged as important mediators of an evolutionary well-preserved mechanism of intercellular communication [53]. Following their release into the microenvironment, EVs, once internalized by endocytosis in target cell, can deliver selective patterns of proteins, bio-active lipids, and nucleic acids [54]. The mechanisms through which EVs interact with the cell surface are complex and mostly depend on the EV origin and recipient cells [55]. Proteins involved in EV-cell interaction include heparan sulphate proteoglycans [56,57], tetraspanins [58], lipids [59,60], 
and extracellular matrix receptors such as integrins [61-63]. EVs' internalization within recipient cells may lead to direct cell stimulation, as well as transfer of receptors and biologically active molecules, such as cytosolic proteins, receptors, bioactive lipids, and nucleic acids [64-66]. Several studies have shown that EVs are particularly enriched in different RNA species, in particular mRNAs and microRNAs (miRNAs), that, when transferred to target cells, remained functional and can modify cellular behavior [65,67-71]. The EV encapsulation efficiently protects RNAs from the degrading activity of enzymes, like RNases, which are present in the extracellular space and in biological fluids [65,72]. It has been demonstrated that the RNA associated with EVs plays a pivotal role in mediating the therapeutic effects of EVs in different pathological conditions, including liver diseases and hepatic fibrosis. In particular, the EV-mediated transfer of non-coding RNAs, such as miRNAs, from stem cells and serum to the injured liver tissue has proved to be effective in ameliorating liver damage and fibrosis [73].

\section{EVs to Treat Liver Diseases}

EVs of different origins contribute to the amelioration of acute liver injuries in different models of damage by improving hepatic oxidant injury, modulating the inflammatory response, and favoring hepatic cell proliferation and survival (Table 1 and Figure 2).

Table 1. Effects of extracellular vesicles (EVs) of different origins on different models of acute liver injuries. CCl4, carbon tetrachloride; IRI, ischemia-reperfusion injury; LPS, lipopolysaccharide; TNF, tumor necrosis factor; D-GalN, D-galactosamine; HLSC, human liver stem cell; MSC, mesenchymal stromal cell; ESC, embryonic stem cell; hUC, human umbilical cord; hASC, human adipose stem cell.

\begin{tabular}{|c|c|c|c|c|}
\hline $\begin{array}{l}\text { In Vivo Models } \\
\text { of Liver Disease }\end{array}$ & EV Sources & $\begin{array}{l}\text { Route and Time of EV } \\
\text { Administration }\end{array}$ & Effects of EV Administration & References \\
\hline $\begin{array}{c}\text { Partial } \\
\text { hepatectomy }\end{array}$ & HLSCs & Tail vein immediately after injury & $\begin{array}{l}\text { Pro-proliferative and anti-apoptotic effect } \\
\text { on hepatocytes }\end{array}$ & [74] \\
\hline $\mathrm{CCl}_{4}$ & ESC-MSCs & $\begin{array}{l}\text { Intra-splenic injection simultaneously } \\
\text { with the damage }\end{array}$ & Pro-proliferative effect on hepatocytes & [75] \\
\hline $\mathrm{CCl}_{4}$ & hUC-MSCs & Tail vein or oral gavage $24 \mathrm{~h}$ post- $\mathrm{CCl}_{4}$ & $\begin{array}{l}\text { Anti-oxidant and anti-apoptotic effects } \\
\text { on hepatocytes }\end{array}$ & [76] \\
\hline $\mathrm{CCl}_{4}$ & hUC-MSCs & Tail vein $24 \mathrm{~h}$ post- $\mathrm{CCl}_{4}$ & $\begin{array}{l}\text { Inhibition of inflammation, oxidative } \\
\text { stress, and apoptosis. Suppression of } \\
\text { hepatic tumor development }\end{array}$ & [77] \\
\hline IRI & Murine BM-MSCs & Tail vein $30 \mathrm{~min}$ before surgery & $\begin{array}{l}\text { Reduction of liver necrosis and } \\
\text { hepatocyte apoptosis by modulating } \\
\text { inflammation. Improvement of } \\
\text { liver function }\end{array}$ & [78] \\
\hline IRI & hiPSC-MSCs & $\begin{array}{c}\text { Inferior vena cava immediately after } \\
\text { reperfusion }\end{array}$ & $\begin{array}{l}\text { Reduce histological damage, } \\
\text { inflammation, apoptosis, and oxidative } \\
\text { stress, and improve hepatic function }\end{array}$ & {$[79,80]$} \\
\hline IRI & hUC-MSCs & Tail vein immediately after surgery & $\begin{array}{l}\text { Reduce apoptosis, neutrophilic infiltrates, } \\
\text { and oxidative stress }\end{array}$ & [81] \\
\hline IRI & $\begin{array}{l}\text { Human BM-MSCs/ } \\
\text { fibroblasts }\end{array}$ & Inferior vena cava before surgery & $\begin{array}{l}\text { Reduction of liver necrosis and } \\
\text { inflammation. Improvement of liver } \\
\text { function and regeneration }\end{array}$ & [82] \\
\hline D-GalN/TNF-alpha & $\begin{array}{l}\text { Murine/human } \\
\text { BM-MSCs }\end{array}$ & $\begin{array}{l}\text { Tail veil or intraperitoneal injection } \\
\text { immediately after damage }\end{array}$ & $\begin{array}{l}\text { Increase in mice survival, reduction of } \\
\text { hepatic inflammation and injury }\end{array}$ & [83] \\
\hline D-GalN/LPS & Men-SCs & Tail vein $24 \mathrm{~h}$ before injury & $\begin{array}{l}\text { Improvement of liver function and } \\
\text { survival, inhibition of apoptosis }\end{array}$ & [84] \\
\hline D-GalN/LPS & hASC & Iliac vein $24 \mathrm{~h}$ after injury & Reduction of necrosis and inflammation & [85] \\
\hline ConA & Murine BM-MSCs & $\begin{array}{l}\text { Intravenous EV injection of } 20 \mu \mathrm{g} / \mathrm{mL} \\
\text { at } 0,8 \text {, and } 16 \mathrm{~h} \text { after injury }\end{array}$ & $\begin{array}{l}\text { Reduction of hepatic necrosis, apoptosis, } \\
\text { and inflammation }\end{array}$ & [86] \\
\hline $\begin{array}{l}\text { IRI and partial } \\
\text { hepatectomy/ } \\
\mathrm{CCl}_{4}\end{array}$ & Rat BM-MSCs & $\begin{array}{l}\text { A single injection via hepatic portal } \\
\text { vein of } 500 \mu \mathrm{g} / \mathrm{mL} \text { of exosome-rich } \\
\text { fractionated secretome before } \\
\text { removing the clamp (IRI) or } 24 \mathrm{~h} \\
\text { post-CCl } \mathrm{Cl}_{4}\end{array}$ & $\begin{array}{l}\text { Improvement of hepatic regeneration and } \\
\text { function, reduction of oxidative stress }\end{array}$ & [87] \\
\hline $\begin{array}{l}\text { IRI and partial } \\
\text { hepatectomy }\end{array}$ & $\begin{array}{l}\text { Murine } \\
\text { hepatocytes }\end{array}$ & $\begin{array}{l}\text { Intravenously EV injection } 24 \text { and } 48 \\
\text { h after IRI, } 24 \mathrm{~h} \text { after hepatectomy }\end{array}$ & Increase of hepatocyte proliferation & [88] \\
\hline
\end{tabular}




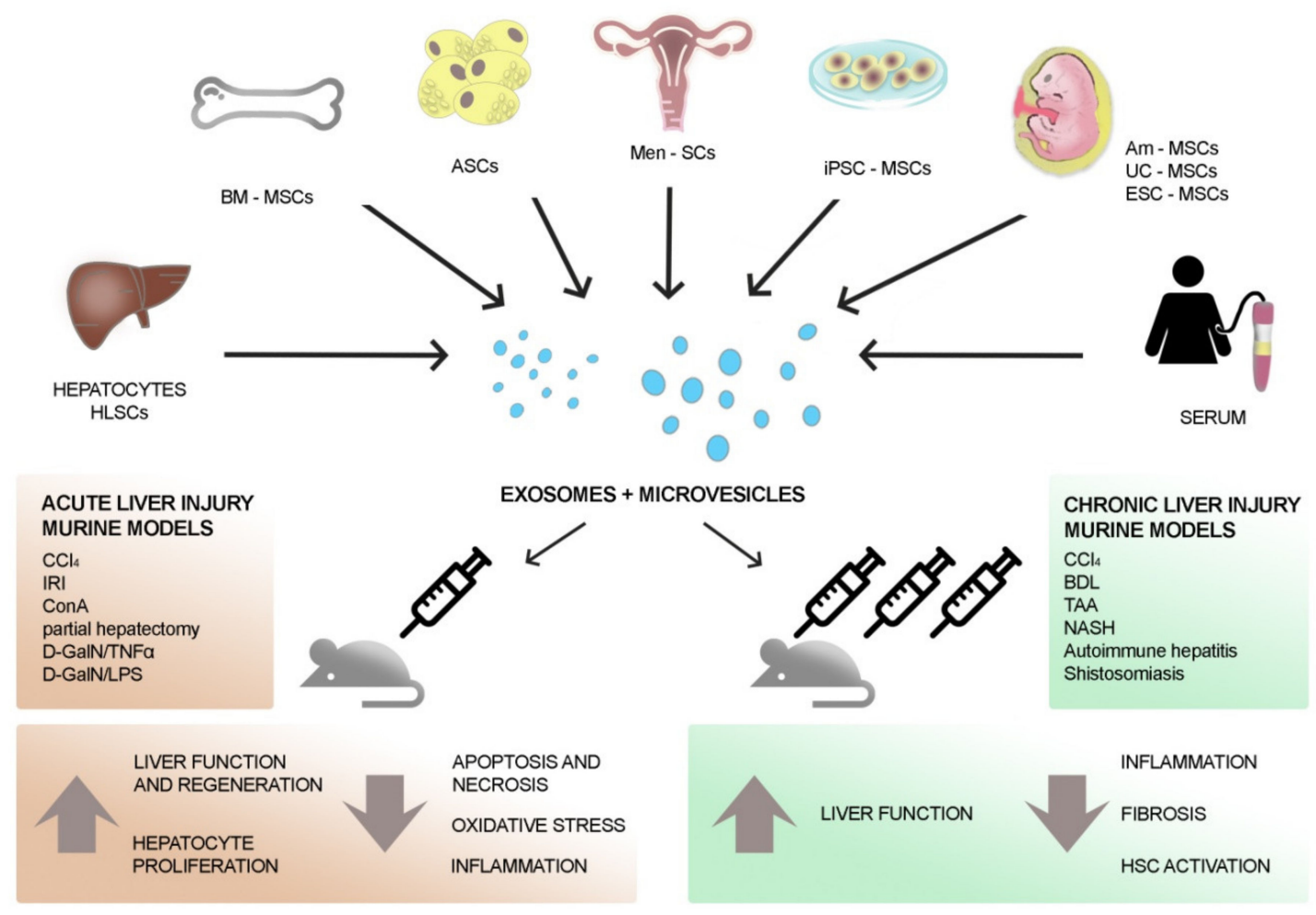

Figure 2. Therapeutic effects of EVs on hepatic injury. EVs secreted by mesenchymal stromal cells (MSCs) of different origin (such as liver, bone marrow, adipose tissue, menstrual blood, amnion, and umbilical cord) show therapeutic benefits on both acute and chronic liver injury models. Moreover, MSC-EVs derived from other stem cells (e.g., embryonic stem cell (ESC), induced pluripotent stem cells (iPSCs)), differentiated cells (e.g., hepatocytes), and serum contribute to the recovery of liver cells after damage. Acute liver injury models often foresee a single injection of EVs that prompts liver regeneration by supporting the proliferation of surviving liver cells and the reduction of oxidative stress and inflammation. Chronic liver injury models require several injections of EVs that restore liver function mainly through the reduction of hepatic fibrosis. $\mathrm{CCl}$, carbon tetrachloride; IRI, ischemia-reperfusion injury; LPS, lipopolysaccharide; TNF, tumor necrosis factor; D-GalN, D-galactosamine; HLSC, human liver stem cell; hCB, human cord blood; hASC, human adipose stem cell; NASH, non-alcoholic steato-hepatitis; TAA, thioacetamide; BDL, bile duct ligation.

The first evidence that EVs can promote liver regeneration was shown by Herrera by injecting EVs derived from human liver stem cells (HLSCs), a mesenchymal stromal cell (MSC)-like population resident in human adult liver, in the model of $70 \%$ hepatectomy in rats. EVs accelerated liver functional and morphological recovery and increased hepatocyte proliferation. The beneficial effects were abrogated by EV pre-treatment with RNase, indicating a pivotal role of EV-associated RNAs in the pro-regenerative effect of EV treatment [74].

The administration of EVs derived from embryonic stem cell-derived MSCs (ESC-MSCs) was found to reverse carbon tetrachloride (CCl4) toxic-liver damage by increasing proliferation of the hepatocytes. The pro-proliferative effect of MSC-EVs was confirmed in different in vitro models of hepatocyte-injuries (acetaminophen and $\mathrm{H} 2 \mathrm{O} 2$ ), where EV treatment up-regulated priming-phase genes, such as tumor necrosis factor alpha (TNF-alpha), interleukin 6 (IL-6), inducible nitric oxide synthase, cyclooxygenase 2, macrophage inflammatory protein 2, and anti-apoptotic proteins (e.g., Bcl-xL), favoring proliferation of survived hepatocytes [75]. Other sources of EVs have been tested in the CCl4 model. EVs fractionated by differential centrifugation from secretome of rat bone marrow (BM)-MSC were shown to attenuate liver injury, by partially restoring liver function and reducing oxidative stress in liver cells [87]. Treatment with EVs derived from human umbilical cord MSCs (hUC-MSC-EVs), either by tail vein administration or by oral gavage, rescued liver failure induced by $\mathrm{CCl} 4$, exerting 
anti-apoptotic and anti-oxidative effects. In particular, it has been demonstrated that the anti-oxidant effect was mediated by the delivery of glutathione peroxidase 1 (GPX1) protein, which reduced hepatic reactive oxygen species (ROS) and inhibited apoptosis induced by oxidative stress, via up-regulation of Bcl-2 and down-regulation of caspase 3 and 9 pathways. Down-regulation of GPX1 in hUC-MSCs and in derived EVs reverted the anti-apoptotic and anti-oxidant effects of hUC-MSC-EVs [82]. Moreover, in a murine model of $\mathrm{CCl} 4$, it has also been shown that treatment with hUC-MSC-EVs suppressed hepatic tumor development, through the anti-oxidant effect [77].

The effect of murine BM-MSC-EVs was also evaluated in a model of hepatic ischemia-reperfusion injury (IRI), where EVs were i.v. administrated $30 \mathrm{~min}$ prior to the surgical procedure. EV administration improved liver function and morphology by reducing the expression of inflammatory mediators both in vitro and in vivo. [78]. Compared with fibroblast-derived EVs, EVs obtained from BM-MSCs showed a stronger potential to attenuate liver injury and to improve organ regeneration after hepatic IRI [82]. Moreover, EVs obtained by hUC-MSCs can protect against hepatic IRI. In this case, EVs were administrated immediately after reperfusion and functional and histological improvements were observed $24 \mathrm{~h}$ after treatment. hUC-MSC-EVs induced a reduction in livers of neutrophil infiltrates; a decrease in mRNA expression level of IL-1-beta, IL-6, TNF-alpha, interferon (IFN)-gamma, and toll-like receptor 4 (TLR4); and alleviated oxidative stress. The authors found that hUC-MSC-EVs shuttled manganese superoxide dismutase (MnSOD), an anti-oxidant enzyme mainly located in the mitochondria. Of interest, knockdown of MnSOD in hUC-MSCs reduced in vivo anti-apoptotic and anti-oxidant effects of hUC-MSC-EVs, indicating a prominent role of this enzyme in the beneficial effect of EVs [81]. Moreover, EVs collected from induced pluripotent stem cells-derived MSCs (iPSC-MSCs) have proved to attenuate IRI $[79,80]$. The in vivo administration of iPSC-MSC-EVs in an IRI rat model reduced the loss of hepatocytes by necrosis and apoptosis, the infiltration of inflammatory cells, and the release of TNF-alpha and IL-6 inflammatory cytokines. Consistently, an increase in hepatocyte proliferation and an amelioration of hepatic damage by oxidative stress were observed after EV treatment [79].

EVs derived from stem cells were also tested in lethal models of hepatic injury (Table 1). BM-MSC-EVs effects were examined in a lethal murine model of hepatic liver failure induced by administration of D-galactosamine (D-GalN) and TNF-alpha. In untreated or vehicle-treated control groups, $24 \mathrm{~h}$ after damage, the survival was $0 \%$. When EVs were administered immediately after injury, there was evidence of an improvement in the survival rate to $57 \%$ using murine (freshly or cryopreserved) BM-MSC-EVs and to 37.5\% when human BM-MSC-EV were used. Improvement of survival was similar with either i.v. or i.p. administration. EV treatment reduced hepatic injury and modulated cytokines expression at the histological level [83]. Vesicles obtained from human menstrual blood-stem cells (MenSC-EV) showed a protective effect in fulminant hepatic failure induced by D-GalN and lipopolysaccharide (LPS). When EVs were administered $24 \mathrm{~h}$ before injury, the survival rate increased to $40 \%$. MenSC-EVs ameliorated liver function, and reduced centrilobular focal necrosis, apoptosis, and inflammation. Moreover, EV treatment down-regulated hepatic and serum levels of pro-inflammatory cytokines (TNF-alpha, IL-6, -8 and 1-beta) [84]. Further, EVs obtained by human adipose stem cells (ASCs) rescued rats with D-GalN and D-GalN/LPS induced acute liver failure, promoting cell proliferation and exerting anti-inflammatory effect. Long-chain non coding (lncRNA) H19 shuttled by EVs was found to be involved in the pro-regenerative effect of ASC-EVs. In fact, EVs obtained from silenced ASCs for lncRNA H19 did not improve survival [85]. The immune-suppressive effect of EVs was also demonstrated on a murine hepatic injury model induced by concanavalin A (con-A), a lectin derived from jack beans. This particular type of liver injury is mediated by the activation of the adaptive immune system and the recruitment of $\mathrm{T}$ cells to the liver. In this context, three EV administrations of murine BM-MSC resulted in reduced liver necrosis, apoptosis, and inflammation, with an increased number of regulatory $\mathrm{T}$ cells among liver non-parenchymal cells. Moreover, EV treatment enhanced mRNA expression of the anti-inflammatory cytokines transforming growth factor (TGF)-beta and hepatocyte growth factor (HGF) [86]. 
EVs derived from murine hepatocytes, but not EVs derived from other terminal differentiated hepatic cells (Kupffer cells or sinusoidal endothelial cells), were found to promote regeneration in liver IRI and in 70\% hepatectomy in vivo models [88]. In both experimental models, EV treatment increased hepatocyte proliferation dose-dependently. Hepatocyte-derived EVs shuttled to target hepatocyte specific sphingolipids and sphingolipid enzymes (neutral ceramidase and sphingosine kinase 2), inducing proliferation via synthesis of sphingosine-1-phosphatase expression [88]. A relevant role of sphingosine kinases and of phosphatase in hepatic regeneration induced by EVs was also confirmed using EVs derived from human iPSC-MSCs in an IRI model [80].

\section{EVs to Treat Liver Fibrosis}

The effects of EVs derived from different sources were also evaluated in different pre-clinical models of chronic liver injuries. EVs were found to counteract fibrosis by reducing hepatic inflammation and collagen deposition (Table 2 and Figure 2).

Table 2. Effects of EVs of different origins on different models of fibrotic liver damages. NASH, non-alcoholic steato-hepatitis; TAA, thioacetamide; HUCPVC, human cord perivascular cell; IGF, insulin-like growth factor; EMT, epithelial-to-mesenchymal transition; SMA, smooth muscle actin.

\begin{tabular}{|c|c|c|c|c|}
\hline $\begin{array}{l}\text { In Vivo Model } \\
\text { of Liver Fibrosis }\end{array}$ & EV Sources & $\begin{array}{l}\text { Route and Time of } \\
\text { EV-Administration }\end{array}$ & Effects of EV-Administration & References \\
\hline $\mathrm{CCl}_{4}$ & hUC-MSCs & $\begin{array}{c}\text { Single EV-dose directly injected into } \\
\text { left and right hepatic lobes, } 6 \text { weeks } \\
\text { after } \mathrm{CCl}_{4} \text { treatment }\end{array}$ & $\begin{array}{l}\text { Inhibition of EMT and protection } \\
\text { of hepatocytes }\end{array}$ & [89] \\
\hline $\mathrm{CCl}_{4}$ & $\begin{array}{l}\text { miR-181-5p } \\
\text { modified murine } \\
\text { ASCs }\end{array}$ & $\begin{array}{l}\text { Intrasplenic injection twice each week } \\
\text { for } 8 \text { weeks concomitantly with } \mathrm{CCl}_{4} \\
\text { treatment }\end{array}$ & $\begin{array}{l}\text { Anti-fibrotic effect, amelioration of } \\
\text { liver function }\end{array}$ & [90] \\
\hline $\mathrm{CCl}_{4} \mathrm{BDL}$ & human-iPSCs & $\begin{array}{l}\text { Tail vein three times a week for the } \\
\text { last two weeks of the } \mathrm{CCl}_{4} \text { study; tail } \\
\text { vein daily injection for the last six } \\
\text { days of duct ligation }\end{array}$ & Reduction of fibrosis and HSC activation & [91] \\
\hline $\mathrm{CCl}_{4} \mathrm{NASH}$ & hAm-MSCs & $\begin{array}{l}\text { Intravenous injection at week } 3 \text { after } \\
\text { the start of } \mathrm{CCl}_{4} \text { treatment and at } \\
\text { week } 3 \text { and } 4 \text { after starting the high } \\
\text { fatty diet to induce NASH }\end{array}$ & $\begin{array}{c}\text { Reduction of Kupffer cells, of expression } \\
\text { levels of pro-inflammatory and } \\
\text { pro-fibrotic cytokines, and of } \\
\text { HSC activation }\end{array}$ & [92] \\
\hline $\mathrm{CCl}_{4}$ & Human BM-MSCs & $\begin{array}{l}\text { Single EV injection through the tail } \\
\text { vein } 8 \text { weeks after } \mathrm{CCl}_{4} \text { treatment }\end{array}$ & $\begin{array}{l}\text { Improvement of liver function and } \\
\text { reduction of fibrosis, inflammation, } \\
\text { and HSC activation via } \\
\text { Wnt/beta-catenin pathway }\end{array}$ & [93] \\
\hline $\mathrm{CCl}_{4} \mathrm{TAA}$ & $\begin{array}{l}\text { Murine and human } \\
\text { serum }\end{array}$ & $\begin{array}{l}\text { Intraperitoneal administration three } \\
\text { times per week during the last two to } \\
\text { three weeks of } \mathrm{CCl}_{4} \text { treatment; } \\
\text { intraperitoenal administration every } \\
\text { day during the last week of thioacetic } \\
\text { treatment experiment }\end{array}$ & $\begin{array}{l}\text { Reduction of the levels of hepatocyte } \\
\text { death, inflammatory infiltrates, AST and } \\
\text { ALT, pro-inflammatory cytokines, } \\
\text { and HSC }\end{array}$ & [94] \\
\hline $\mathrm{CCl}_{4}$ & $\begin{array}{l}\text { Murine and human } \\
\text { hepatocytes }\end{array}$ & $\begin{array}{l}\text { Intraperitoneal administration three } \\
\text { times per week during the last two } \\
\text { weeks of the experiment }\end{array}$ & $\begin{array}{l}\text { Reduction of alpha-SMA expression and } \\
\text { of fibrosis and inflammation }\end{array}$ & [95] \\
\hline TAA & hESC-MSCs & Intrasplenic injection & $\begin{array}{l}\text { Reduction of fibrosis and immune cell } \\
\text { infiltration, up-regulation of } \\
\text { anti-apoptotic and } \\
\text { anti-inflammatory genes }\end{array}$ & [96] \\
\hline TAA & hESC-MSCs & $\begin{array}{l}\text { Intraperitoneal injection of free or } \\
\text { hydrogel-loaded EVs }\end{array}$ & $\begin{array}{c}\text { Reduction of necrosis, inflammation, } \\
\text { and fibrosis }\end{array}$ & [97] \\
\hline TAA & $\begin{array}{l}\text { HUCPVCs } \\
\text { engineered to } \\
\text { produce IGF-1 }\end{array}$ & $\begin{array}{l}\text { On week } 6 \text { of treatment, tail vein } \\
\text { injection every } 5 \text { days } \\
\text { (total of three doses) }\end{array}$ & $\begin{array}{l}\text { Reduction of collagen deposition and } \\
\text { expression of fibrogenic transcripts }\end{array}$ & [98] \\
\hline $\begin{array}{l}\text { Autoimmune } \\
\text { hepatitis }\end{array}$ & $\begin{array}{l}\text { Murine BM-MSCs } \\
\text { engineered with } \\
\text { miR-223 }\end{array}$ & $\begin{array}{l}\text { Administration of EVs at day 21, 28, } \\
\text { and } 35\end{array}$ & $\begin{array}{l}\text { Improvement of liver structure and } \\
\text { function and of lymphocyte infiltration }\end{array}$ & [99] \\
\hline NASH & HLSCs & $\begin{array}{l}\text { Intravenous twice a weeks starting } \\
\text { from week } 2 \text { of diet }\end{array}$ & $\begin{array}{l}\text { Improvement of liver function and } \\
\text { reduction of fibrosis and inflammation }\end{array}$ & [100] \\
\hline Schistosomiasis & hUCMSCs & $\begin{array}{l}\text { Intravenous injection at the fourth or } \\
\text { at the sixth week after infection }\end{array}$ & $\begin{array}{c}\text { Increased mice survival, improvement of } \\
\text { liver function, and reduction of fibrosis } \\
\text { and inflammation }\end{array}$ & [101] \\
\hline
\end{tabular}


CCl4 is the most widely used hepatotoxin to develop liver fibrosis in different strains of mice and rats. EVs derived from different types of stem cells, but also from serum and from differentiated cells, were tested in this model. Firstly, EVs derived from hUC-MSCs were shown to be able to alleviate hepatic inflammation and collagen deposition in CCl4-induced fibrosis. At molecular level, collagen I and III and TGF-beta transcripts expression levels were reduced by EV-administration. Moreover, Smad2 phosphorylation, an important component of epithelial-to-mesenchymal transition (EMT)-pathway, was found to be reduced after EV-treatment [89]. EVs obtained by murine ASCs over-expressing miR-181-5p attenuated liver injury and down-regulated fibrotic transcripts, such as collagen I, vimentin, alpha-smooth muscle actin (alpha-SMA), and fibronectin, in CCl4-induced liver fibrosis. In vitro, miR-181-5p down-regulated signal transducer and activator of transcription (STAT)-3 and Bcl-2, thus suppressing hepatic stellate cells' (HSCs) activation, and induced autophagy through the up-regulation of Beclin-1 [90]. Moreover, the lentiviral-driven miR-122 expression in ASCs enhanced their therapeutic effect in CCl4-induced liver fibrosis, by reducing HSC activation and collagen deposition. In vitro, ASC-EVs carrying miR-122 down-regulated the expression of several genes involved in proliferation and collagen maturation, such as cyclin G1 (CCNG1), insulin-like growth factor receptor 1 (IGF1R), and prolyl-4-hydroxylase a1 (P4HA1) [102]. EVs from murine iPSCs modulated in vitro HSC activation and had an anti-fibrotic effect not only in CCl4 murine model, but also in bile duct ligation (BDL)-induced liver fibrosis. Molecular analyses of liver tissues demonstrated down-regulation of profibrogenic genes alpha-SMA, collagen I, and tissue inhibitor of metalloproteinase 1 (TIMP-1) [91]. In CCl4-induced chronic liver disease, EVs from amnion-derived MSCs (Am-MSC) reduced fibrosis, Kupffer cell number, and HSC activation. The in vitro effects of EVs on Kupffer cells were further investigated. Am-MSC-EV treatment reduced the expression level of pro-inflammatory molecules, such as TNF-alpha, IL-1-beta, and MCP-1, in Kupffer cells stimulated with LPS. The increase in nuclear factor kappa-light-chain-enhancer of activated B cells (NF-kB) transcriptional activity induced by LPS was reduced by Am-MSC-EV treatment, through the inhibition of the phosphorylation of IkB-alpha and p65. As Am-MSC-EV did not decrease NF-kB transcriptional activity induced by TNF receptor associated factor (TRAF), the authors suggested that AMSC-EV may suppress the earlier steps of the LPS/TLR4 signaling pathway [92]. EVs derived from human BM-MSCs have shown similar effects in a rat model of CCl4 -induced liver fibrosis, and the reduced HSC activation has been linked to the inhibition of several genes in the Wnt signalin pathway, such as peroxisome proliferator-activated receptor (PPAR)-gamma, beta-catenin, WNT3a, and WNT10b. Moreover, the EV-treated animals exhibited reduced mRNA expression levels of inflammatory cytokines IL-1, IL-2, IL-6, IL-8, IL-10, and TNF-alpha [93]. Serum EVs from healthy subjects dose-dependently inhibited fibrosis in CCl4-injured liver and reduced alpha-SMA expression, indicating a reduction of HSC activation. Protein array showed a reduction of some pro-inflammatory cytokines and chemokines, such as IFN-gamma, IL-2, IL-4, and TNF-alpha in liver tissue, as in the circulation of CCl4-treated mice. Different miRNAs shuttled by serum EVs have a predicted anti-fibrotic effect. Among them, miR-34c-3p, -151-3p, -483-5p, -532-5p, and -687 have been demonstrated to be implicated in the anti-fibrotic effect of serum-EVs using specific miRNA-mimics in in vitro experiments on activated HSCs [94]. Moreover, pro-fibrotic genes alpha-SMA, connective tissue growth factor (CCN2), and collagen I induced by CCl4 were dose-dependently reduced by treatment with hepatocyte EVs. Moreover, inflammatory response to $\mathrm{CCl} 4$ was suppressed by hepatocyte EV treatment. In particular, a reduction of the frequency of hepatic monocytes and macrophages was reduced by hepatocyte EV treatment. Protein microarray analysis indicated that hepatocyte $\mathrm{EV}$ administration reduced levels of the fibrosis-related factors TIMP-1, chemokine (C-C motif) ligand (CCL)-3, CCL-5, and CCL-12. Interestingly, RNA sequencing of liver tissues revealed that hepatocyte-EV treatment induced significant differences in the expression of 233 CCl4-regulated genes. These were associated with fibrosis, cell division, extracellular matrix, drug detoxification, membrane trafficking, and immunity [95].

In a thioacetamide (TAA)-induced chronic liver injury model, an anti-fibrotic effect of EVs obtained from hESC-derived MSCs has been reported. Molecular analyses showed up-regulation of matrix 
metalloproteinase (MMP) 9 and 13, anti-apoptotic genes, and anti-inflammatory cytokines (IL-10 and TGF-beta) with concomitant down-regulation of collagen, alpha-SMA, and TIMP-1 transcripts, and of pro-apoptotic and pro-inflammatory genes (TNF-alpha and IL-2) [96]. Rapid clearance of EVs from target organ may reduce the efficiency of EV treatments. For this reason, in a TAA model of hepatic fibrosis, the possibility of using EVs encapsulated in polyethylene glycol macromeres (gel-EVs) was tested. In this condition, the gel-EVs were swollen gradually and the EVs were progressively released over 1 month and accumulated in liver, as indicated by in vivo tracking experiments. Histological and molecular analyses demonstrated superior anti-fibrotic, anti-apoptotic, and anti-inflammatory effects of gel-EVs in comparison with free-EVs [97]. EVs derived from human cord perivascular cells (HUCPVCs), an alternative source of MSCs, were also tested in a TAA-chronic liver injury model. HUCPVC-EVs over-expressing insulin growth factor 1 (IGF-1) showed, in comparison with naive HUCPVC-EVs, a stronger anti-fibrotic effect and were the only ones able to reduce the activation of HSCs [98].

Different types of EVs have been also tested in different animal models of non-alcoholic steatohepatitis (NASH). Am-MSC-EVs improved histological findings and pro-inflammatory factors expression in rats with NASH induced by feeding them with high-fat diet for four weeks. Am-MSC-EVs suppressed the activation of pro-inflammatory M1 macrophages and down-regulated the expression of pro-inflammatory cytokines such as TNF-alpha, IL-1-beta, and IL-6 [92]. EVs derived from HLSCs influenced the progression of NASH induced by a diet deprived of methionine and choline. HLSC-EVs treatment improved liver function and morphology by reducing liver fibrosis and inflammation. At molecular level, 28 out of 29 fibrosis-associated genes up-regulated in NASH livers were significantly down-regulated by HLSC-EV administration. The list of reverted genes included collagen 1, alpha-SMA, TGF-beta, and the gene latent-transforming growth factor beta-binding protein 1 (Ltbp1), genes involved in tissue remodeling (TIMP-1 and MMP-1a, -13, -14, and -8) and in inflammation (TNF-alpha and IL-1-beta). The anti-inflammatory effect of HLSC-EV-treatment was also indicated by the reduction of inflammatory cells accumulated in the liver and by the increase in IL-10 expression level in NASH mice treated with HLSC-EVs [100].

Chronic inflammation due to autoimmune hepatitis may cause development of liver fibrosis. In a murine model of autoimmune hepatitis, induced by intraperitoneal injection of $\mathrm{S} 100$ liver antigen, EVs derived from naive BM-MSC or from BM-MSC transfected with miR-223 were able to revert liver injury by regulation of inflammasome NLRP3 and caspase-1 [99]. Schistosomiasis is another cause of chronic liver inflammation. Recently, EVs obtained from hUC-MSC have proved to alleviate $\mathrm{S}$. japonicum-induced liver injury, thus increasing the survival of schistosome-infected mice. In vivo administration of hUCMSC-EV reduced hepatic fibrosis by down-regulating the expression of alpha-SMA, collagen I, and collagen III. Moreover, a decrease in mRNA expression levels of IFN-gamma, TNF-alpha, and IL-beta has also been observed after hUCMSC-EV administration [101].

\section{Advantages and Need for Future Clinical Applications of EVs}

Compared with cell-based therapy, EVs therapeutic approach has some advantages. EVs exhibit a superior efficacy profile of cell-based therapy as they pass biological barriers and act as effective carriers of different molecules (RNAs, proteins, and lipids). EVs appear more stable and suitable for long term storage, in comparison with the cells of origin. Interestingly, the possibility to lyophilize purified EVs has recently been shown [103]. This could allow the production of ready-to-use batches of EVs that can be easily transported. However, further studies are needed to prove that lyophilization does not alter the EVs' morphology and functionality. Moreover, no adverse immune responses have been reported in patients undergoing allogeneic administration of MSC-EVs [104] and a significant benefit of MSC-EVs in respect to MSC-treatment is the chance to avoid potential tumorigenicity of the cells of origin. Actually, no evidence of oncogenic potential of MSC-EVs has been reported and in vitro and in vivo experiments indicated that MSC-EVs can inhibit tumor growth by interfering with cell 
cycle and inducing apoptosis and/or necrosis of different cancer cell lines [105]. Anti-tumor activity has also been reported for HLSC-EVs [106].

A lot of challenges need to be addressed prior to the application of EVs in clinical trials. First, the choice of the best EV source must be established. EVs can be obtained from different cellular sources, in particular from various type of stem cells maintained in different culture conditions (e.g., hypoxia, growth factors), which may modify the contents of released EVs and influence their effects in tissue regeneration [107]. Despite these differences, all these studies indicated that EVs may be a promising cell-free treatment for liver diseases. Even though a direct comparison of the different cell sources is still missing, we can speculate that hUC-MSCs could be one of the best cellular sources, being more accessible in respect to BM-MSCs and not involving ethical objections, as reported for ESCs and iPSCs. Moreover, HLSCs are a good candidate stem cell source to obtain EVs for tissue regeneration. HLSC-EVs have been tested in different experimental animal models of acute and chronic liver disease [74,100]. Of interest, HLSC-EVs have also been used in chronic kidney diseases, such as diabetic nephropathy and aristolochic acid-induced nephropathy, both characterized by fibrosis development. In these two animal models, HLSC-EVs exhibited similar therapeutic effects of BM-MSC-EVs, despite the different molecular mechanisms [108-110].

Moreover, the best way to obtain the quantity of EVs necessary for clinical application has to be standardized. In addition, it is necessary to validate the dosage and the half-life of EVs, freshly isolated or after cryopreservation or lyophilization. The content of EVs needs to be deeply investigated, in order to understand which EV components could act as pro-regenerative or anti-fibrotic factors and which could possibly be harmful. Moreover, the unknown negative effects of single or repeated administration have to be clarified.

\section{Conclusions}

EVs from various sources, such as serum, hepatic cells, and different type of stem cells (embryonic, adult, bone marrow, liver), have been tested in different animal models of liver disease using different doses, regimens, and time of administration. EVs of different origins appear to attenuate fibrosis in pre-clinical models mimicking different pathogenic conditions. EVs contain biologically active molecules such as proteins, mRNAs, and non coding RNAs that can play critical roles in modulating immune cells, leading to reduced inflammation and consequently fibrosis. EVs can also directly modify the activation state of the HSCs, reducing the deposition of fibrotic factors and secretion of pro-inflammatory molecules.

Despite that the benefits of EVs in different models of liver damage, in particular in fibrosis, have been extensively evaluated, further studies are needed to elucidate the mechanisms of action. One possible target of therapeutic EVs in liver fibrosis could be the HSC. The activation of HSC is a critical event during liver fibrosis and is controlled by several cytokines, growth factors, and small RNA species such as miRNAs [73]. The molecular content of EVs derived from MSCs, hepatocytes, and serum may suppress the myofibroblast-like phenotype of HSC through the inhibition of different molecular pathways mainly involved in HSC proliferation and collagen synthesis (Figure 3). In liver fibrosis, the therapeutic effect of EVs could be attributed, at least in part, to the action of EV-associated miRNAs that are down-regulated in HSC during fibrosis $[90,94,99,102]$. One could speculate that EVs could alleviate hepatic fibrosis by restoring physiological expression levels of miRNAs in liver tissue.

The preclinical data summarized in this review support the idea that cell-free therapy, with different types of EVs, could be a novel alternative therapeutic approach for liver diseases and in particular for liver fibrosis. However, before implementing this promising approach, numerous problems have to be solved, such as large-scale EV production and safety. 


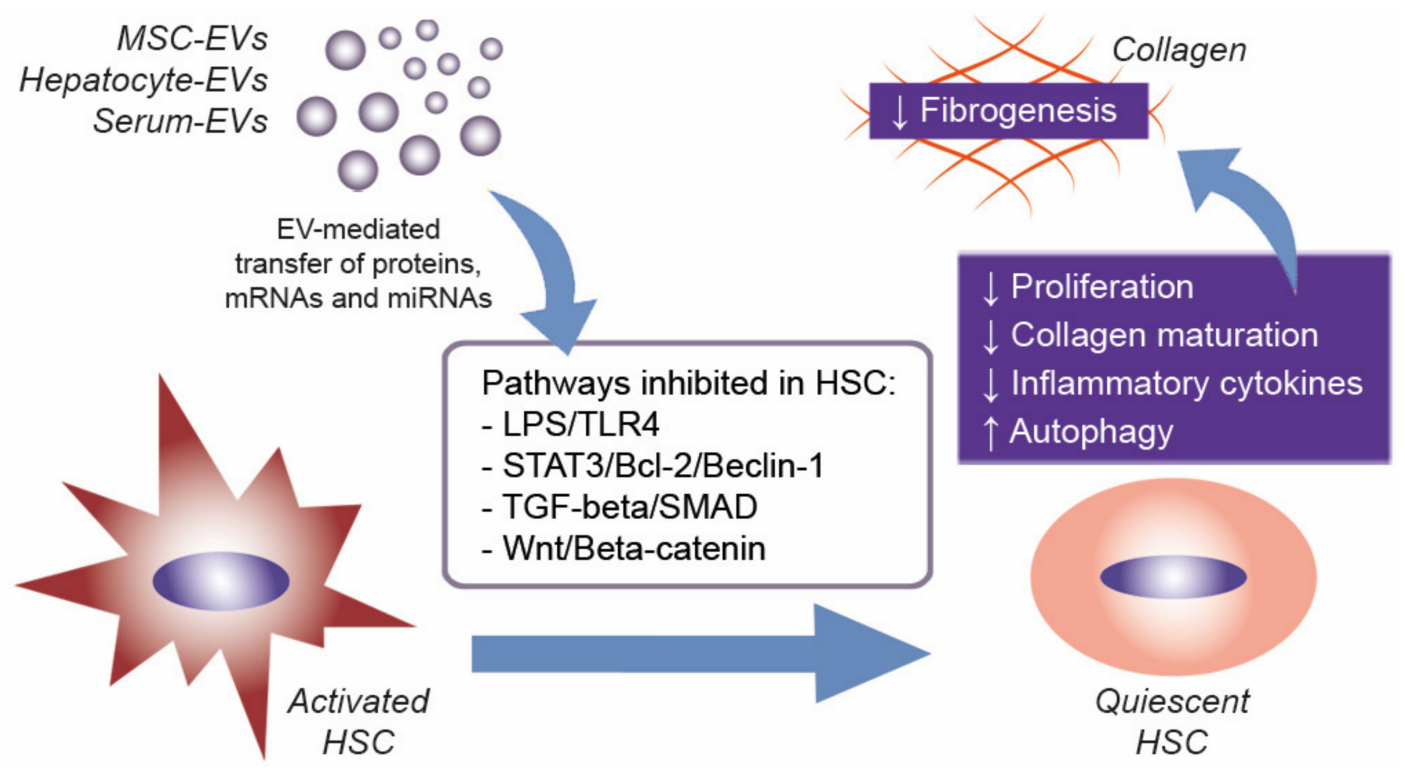

Figure 3. EV effects on HSC during liver fibrosis. EVs derived from different sources, such as MSCs, hepatocytes, and serum, contain proteins and specific patterns of mRNAs and miRNAs that can modulate a number of molecular pathways in target cells. In liver fibrosis, the possible EV uptake by activated HSC could revert its quiescent state, thus reducing HSC activation and fibrogenesis. TGF, transforming growth factor; TLR4, toll-like receptor 4; SMAD, small mothers against decapentaplegic; STAT, signal transducer and activator of transcription.

Author Contributions: S.B. And G.C. (Giulia Chiabotto) performed the research of the pertinent literature, and designed and drafted the manuscript. G.C. (Giovanni Camussi) revised and edited the manuscript. All authors have read and agreed to the published version of the manuscript.

Funding: This work was supported by a grant from "Terapie avanzate per processi fibrotici cronici" (Progetto EV-ER, codice domanda 320-40, Regione Piemonte).

Acknowledgments: The authors would like to thank Valeria Chiabotto for figure realization.

Conflicts of Interest: G.C. (Giovanni Camussi) is a component of Scientific Advisory Board of Unicyte AG. The authors declare no conflict of interest.

$\begin{array}{ll}\text { Abbreviations } \\ \text { EVs } & \text { Extracellular Vesicles } \\ \text { MVs } & \text { Microvesicles } \\ \text { ILVs } & \text { Intraluminal Vesicles } \\ \text { MVBs } & \text { Multivesicular Bodies } \\ \text { ESCRT } & \text { Endosomal Sorting Complex Required for Transport } \\ \text { HRS } & \text { Hepatocyte Growth Factor-Regulated Tyrosine Kinase Substrate } \\ \text { TSG101 } & \text { Tumor Susceptibility Gene 101 Protein } \\ \text { ALIX } & \text { Apoptosis-Linked Gene-2 Interacting Protein X } \\ \text { VPS4 } & \text { Vacuolar Protein Sorting-Associated Protein 4 } \\ \text { GTPase } & \text { Guanosine Triphosphatase } \\ \text { SNAREs } & \text { Soluble N-Ethylmaleimide-Sensitive Factor Attachment Protein Receptors } \\ \text { ARRDC1 } & \text { Arrestin Domain-Containing Protein-1 } \\ \text { ROCK } & \text { Rho-Associated Protein Kinase } \\ \text { ARF } & \text { ADP-Ribosylation Factor } \\ \text { miRNA } & \text { MicroRNA } \\ \text { HLSCs } & \text { Human Liver Stem Cells } \\ \text { MSCs } & \text { Mesenchymal Stromal Cells } \\ \text { ESC-MSCs } & \text { Embryonic Stem Cell-Derived MSCs }\end{array}$




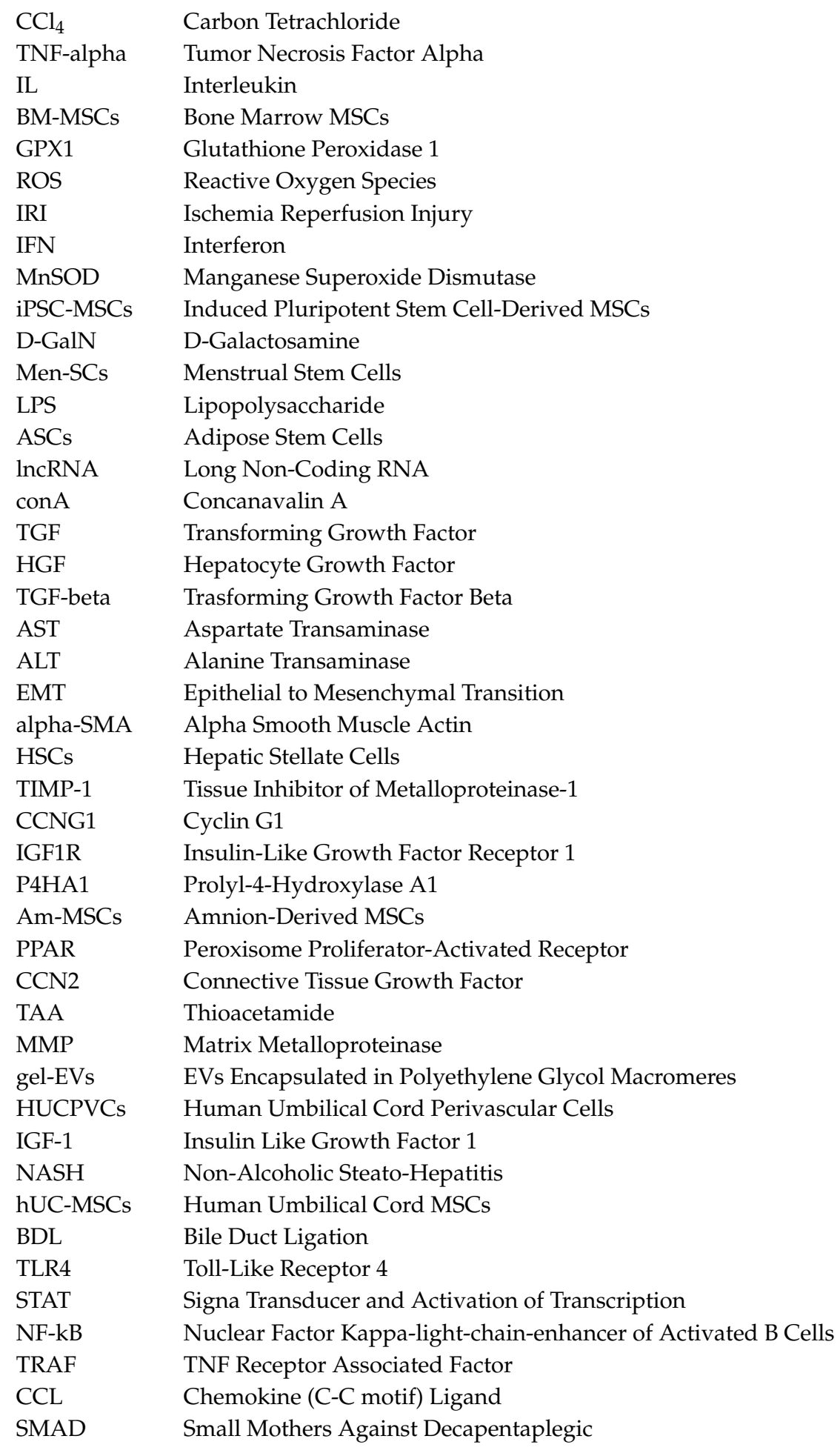

\section{References}

1. György, B.; Szabó, T.G.; Pásztói, M.; Pál, Z.; Misják, P.; Aradi, B.; László, V.; Pállinger, E.; Pap, E.; Kittel, A.; et al. Membrane Vesicles, Current State-of-the-Art: Emerging Role of Extracellular Vesicles. Cell. Mol. Life Sci. 2011, 68, 2667-2688. [CrossRef] [PubMed]

2. Yáñez-Mó, M.; Siljander, P.R.-M.; Andreu, Z.; Zavec, A.B.; Borràs, F.E.; Buzas, E.I.; Buzas, K.; Casal, E.; Cappello, F.; Carvalho, J.; et al. Biological Properties of Extracellular Vesicles and Their Physiological Functions. J. Extracell. Vesicles 2015, 4, 27066. [CrossRef] [PubMed] 
3. Cocucci, E.; Meldolesi, J. Ectosomes and Exosomes: Shedding the Confusion between Extracellular Vesicles. Trends Cell Biol. 2015, 25, 364-372. [CrossRef] [PubMed]

4. Hirsova, P.; Ibrahim, S.H.; Verma, V.K.; Morton, L.A.; Shah, V.H.; LaRusso, N.F.; Gores, G.J.; Malhi, H. Extracellular Vesicles in Liver Pathobiology: Small Particles with Big Impact. Hepatology 2016, 64, 2219-2233. [CrossRef] [PubMed]

5. Meldolesi, J. Exosomes and Ectosomes in Intercellular Communication. Curr. Biol. 2018, 28, R435-R444. [CrossRef] [PubMed]

6. Hristov, M.; Erl, W.; Linder, S.; Weber, P.C. Apoptotic Bodies from Endothelial Cells Enhance the Number and Initiate the Differentiation of Human Endothelial Progenitor Cells in Vitro. Blood 2004, 104, 2761-2766. [CrossRef]

7. Kowal, J.; Arras, G.; Colombo, M.; Jouve, M.; Morath, J.P.; Primdal-Bengtson, B.; Dingli, F.; Loew, D.; Tkach, M.; Théry, C. Proteomic Comparison Defines Novel Markers to Characterize Heterogeneous Populations of Extracellular Vesicle Subtypes. Proc. Natl. Acad. Sci. USA 2016, 113, E968-E977. [CrossRef]

8. Witwer, K.W.; Buzás, E.I.; Bemis, L.T.; Bora, A.; Lässer, C.; Lötvall, J.; Nolte-'t Hoen, E.N.; Piper, M.G.; Sivaraman, S.; Skog, J.; et al. Standardization of Sample Collection, Isolation and Analysis Methods in Extracellular Vesicle Research. J. Extracell. Vesicles 2013, 2. [CrossRef]

9. Hessvik, N.P.; Llorente, A. Current knowledge on exosome biogenesis and release. Cell Mol. Life Sci. 2018, 75, 193-208. [CrossRef]

10. Hanson, P.I.; Cashikar, A. Multivesicular Body Morphogenesis. Annu. Rev. Cell Dev. Biol. 2012, 28, 337-362. [CrossRef]

11. Hurley, J.H.; Odorizzi, G. Get on the Exosome Bus with ALIX. Nat. Cell Biol. 2012, 14, 654-655. [CrossRef] [PubMed]

12. Colombo, M.; Moita, C.; van Niel, G.; Kowal, J.; Vigneron, J.; Benaroch, P.; Manel, N.; Moita, L.F.; Théry, C.; Raposo, G. Analysis of ESCRT Functions in Exosome Biogenesis, Composition and Secretion Highlights the Heterogeneity of Extracellular Vesicles. J. Cell. Sci. 2013, 126, 5553-5565. [CrossRef] [PubMed]

13. Tamai, K.; Tanaka, N.; Nakano, T.; Kakazu, E.; Kondo, Y.; Inoue, J.; Shiina, M.; Fukushima, K.; Hoshino, T.; Sano, K.; et al. Exosome Secretion of Dendritic Cells Is Regulated by Hrs, an ESCRT-0 Protein. Biochem. Biophys. Res. Commun. 2010, 399, 384-390. [CrossRef] [PubMed]

14. Razi, M.; Futter, C.E. Distinct Roles for Tsg101 and Hrs in Multivesicular Body Formation and Inward Vesiculation. Mol. Biol. Cell 2006, 17, 3469-3483. [CrossRef]

15. Baietti, M.F.; Zhang, Z.; Mortier, E.; Melchior, A.; Degeest, G.; Geeraerts, A.; Ivarsson, Y.; Depoortere, F.; Coomans, C.; Vermeiren, E.; et al. Syndecan-Syntenin-ALIX Regulates the Biogenesis of Exosomes. Nat. Cell Biol. 2012, 14, 677-685. [CrossRef]

16. Babst, M.; Davies, B.A.; Katzmann, D.J. Regulation of Vps4 during MVB Sorting and Cytokinesis. Traffic 2011, 12, 1298-1305. [CrossRef]

17. Stuffers, S.; Sem Wegner, C.; Stenmark, H.; Brech, A. Multivesicular Endosome Biogenesis in the Absence of ESCRTs. Traffic 2009, 10, 925-937. [CrossRef]

18. Escola, J.M.; Kleijmeer, M.J.; Stoorvogel, W.; Griffith, J.M.; Yoshie, O.; Geuze, H.J. Selective Enrichment of Tetraspan Proteins on the Internal Vesicles of Multivesicular Endosomes and on Exosomes Secreted by Human B-Lymphocytes. J. Biol. Chem. 1998, 273, 20121-20127. [CrossRef]

19. Buschow, S.I.; Nolte-'t Hoen, E.N.M.; van Niel, G.; Pols, M.S.; ten Broeke, T.; Lauwen, M.; Ossendorp, F.; Melief, C.J.M.; Raposo, G.; Wubbolts, R.; et al. MHC II in Dendritic Cells Is Targeted to Lysosomes or T Cell-Induced Exosomes via Distinct Multivesicular Body Pathways. Traffic 2009, 10, 1528-1542. [CrossRef]

20. Andreu, Z.; Yáñez-Mó, M. Tetraspanins in Extracellular Vesicle Formation and Function. Front. Immunol. 2014, 5, 442. [CrossRef]

21. Van Niel, G.; Charrin, S.; Simoes, S.; Romao, M.; Rochin, L.; Saftig, P.; Marks, M.S.; Rubinstein, E.; Raposo, G. The Tetraspanin CD63 Regulates ESCRT-Independent and-Dependent Endosomal Sorting during Melanogenesis. Dev. Cell 2011, 21, 708-721. [CrossRef]

22. Chairoungdua, A.; Smith, D.L.; Pochard, P.; Hull, M.; Caplan, M.J. Exosome Release of $\beta$-Catenin: A Novel Mechanism That Antagonizes Wnt Signaling. J. Cell Biol. 2010, 190, 1079-1091. [CrossRef] [PubMed]

23. Nazarenko, I.; Rana, S.; Baumann, A.; McAlear, J.; Hellwig, A.; Trendelenburg, M.; Lochnit, G.; Preissner, K.T.; Zöller, M. Cell Surface Tetraspanin Tspan8 Contributes to Molecular Pathways of Exosome-Induced Endothelial Cell Activation. Cancer Res. 2010, 70, 1668-1678. [CrossRef] [PubMed] 
24. Perez-Hernandez, D.; Gutiérrez-Vázquez, C.; Jorge, I.; López-Martín, S.; Ursa, A.; Sánchez-Madrid, F.; Vázquez, J.; Yáñez-Mó, M. The Intracellular Interactome of Tetraspanin-Enriched Microdomains Reveals Their Function as Sorting Machineries toward Exosomes. J. Biol. Chem. 2013, 288, 11649-11661. [CrossRef] [PubMed]

25. Hurwitz, S.N.; Conlon, M.M.; Rider, M.A.; Brownstein, N.C.; Meckes, D.G. Nanoparticle Analysis Sheds Budding Insights into Genetic Drivers of Extracellular Vesicle Biogenesis. J. Extracell. Vesicles 2016, 5, 31295. [CrossRef]

26. Brügger, B.; Bankaitis, V.A. Lipids and Vesicular Transport. Biochim. Biophys. Acta 2012, 1821, 1039. [CrossRef]

27. Trajkovic, K.; Hsu, C.; Chiantia, S.; Rajendran, L.; Wenzel, D.; Wieland, F.; Schwille, P.; Brügger, B.; Simons, M. Ceramide Triggers Budding of Exosome Vesicles into Multivesicular Endosomes. Science 2008, 319, 1244-1247. [CrossRef]

28. Mittelbrunn, M.; Gutiérrez-Vázquez, C.; Villarroya-Beltri, C.; González, S.; Sánchez-Cabo, F.; González, M.Á.; Bernad, A.; Sánchez-Madrid, F. Unidirectional Transfer of MicroRNA-Loaded Exosomes from T Cells to Antigen-Presenting Cells. Nat. Commun. 2011, 2, 282. [CrossRef]

29. Savina, A.; Furlán, M.; Vidal, M.; Colombo, M.I. Exosome Release Is Regulated by a Calcium-Dependent Mechanism in K562 Cells. J. Biol. Chem. 2003, 278, 20083-20090. [CrossRef]

30. Krämer-Albers, E.-M.; Bretz, N.; Tenzer, S.; Winterstein, C.; Möbius, W.; Berger, H.; Nave, K.-A.; Schild, H.; Trotter, J. Oligodendrocytes Secrete Exosomes Containing Major Myelin and Stress-Protective Proteins: Trophic Support for Axons? Proteom. Clin. Appl 2007, 1, 1446-1461. [CrossRef]

31. Hoshino, D.; Kirkbride, K.C.; Costello, K.; Clark, E.S.; Sinha, S.; Grega-Larson, N.; Tyska, M.J.; Weaver, A.M. Exosome Secretion Is Enhanced by Invadopodia and Drives Invasive Behavior. Cell Rep. 2013, 5, 1159-1168. [CrossRef]

32. Granger, E.; McNee, G.; Allan, V.; Woodman, P. The Role of the Cytoskeleton and Molecular Motors in Endosomal Dynamics. Semin. Cell Dev. Biol. 2014, 31, 20-29. [CrossRef] [PubMed]

33. Sinha, S.; Hoshino, D.; Hong, N.H.; Kirkbride, K.C.; Grega-Larson, N.E.; Seiki, M.; Tyska, M.J.; Weaver, A.M. Cortactin Promotes Exosome Secretion by Controlling Branched Actin Dynamics. J. Cell Biol. 2016, 214, 197-213. [CrossRef] [PubMed]

34. Antonyak, M.A.; Wilson, K.F.; Cerione, R.A. R(h)Oads to Microvesicles. Small GTPases 2012, 3, $219-224$. [CrossRef] [PubMed]

35. Hyenne, V.; Apaydin, A.; Rodriguez, D.; Spiegelhalter, C.; Hoff-Yoessle, S.; Diem, M.; Tak, S.; Lefebvre, O.; Schwab, Y.; Goetz, J.G.; et al. RAL-1 Controls Multivesicular Body Biogenesis and Exosome Secretion. J. Cell Biol. 2015, 211, 27-37. [CrossRef] [PubMed]

36. Bonifacino, J.S.; Glick, B.S. The Mechanisms of Vesicle Budding and Fusion. Cell 2004, 116, 153-166. [CrossRef]

37. Zylbersztejn, K.; Galli, T. Vesicular Traffic in Cell Navigation. FEBS J. 2011, 278, 4497-4505. [CrossRef]

38. Stenmark, H. Rab GTPases as Coordinators of Vesicle Traffic. Nat. Rev. Mol. Cell Biol. 2009, 10, 513-525. [CrossRef]

39. Zhen, Y.; Stenmark, H. Cellular Functions of Rab GTPases at a Glance. J. Cell. Sci. 2015, 128, 3171-3176. [CrossRef]

40. Savina, A.; Fader, C.M.; Damiani, M.T.; Colombo, M.I. Rab11 Promotes Docking and Fusion of Multivesicular Bodies in a Calcium-Dependent Manner. Traffic 2005, 6, 131-143. [CrossRef]

41. Ostrowski, M.; Carmo, N.B.; Krumeich, S.; Fanget, I.; Raposo, G.; Savina, A.; Moita, C.F.; Schauer, K.; Hume, A.N.; Freitas, R.P.; et al. Rab27a and Rab27b Control Different Steps of the Exosome Secretion Pathway. Nat. Cell Biol. 2010, 12, 19-30. [CrossRef] [PubMed]

42. Bobrie, A.; Krumeich, S.; Reyal, F.; Recchi, C.; Moita, L.F.; Seabra, M.C.; Ostrowski, M.; Théry, C. Rab27a Supports Exosome-Dependent and -Independent Mechanisms That Modify the Tumor Microenvironment and Can Promote Tumor Progression. Cancer Res. 2012, 72, 4920-4930. [CrossRef]

43. Hsu, C.; Morohashi, Y.; Yoshimura, S.-I.; Manrique-Hoyos, N.; Jung, S.; Lauterbach, M.A.; Bakhti, M.; Grønborg, M.; Möbius, W.; Rhee, J.; et al. Regulation of Exosome Secretion by Rab35 and Its GTPase-Activating Proteins TBC1D10A-C. J. Cell Biol. 2010, 189, 223-232. [CrossRef] [PubMed]

44. Nabhan, J.F.; Hu, R.; Oh, R.S.; Cohen, S.N.; Lu, Q. Formation and Release of Arrestin Domain-Containing Protein 1-Mediated Microvesicles (ARMMs) at Plasma Membrane by Recruitment of TSG101 Protein. Proc. Natl. Acad. Sci. USA 2012, 109, 4146-4151. [CrossRef] [PubMed] 
45. Muralidharan-Chari, V.; Clancy, J.W.; Sedgwick, A.; D'Souza-Schorey, C. Microvesicles: Mediators of Extracellular Communication during Cancer Progression. J. Cell. Sci. 2010, 123, 1603-1611. [CrossRef]

46. McMahon, H.T.; Boucrot, E. Membrane Curvature at a Glance. J. Cell. Sci. 2015, 128, 1065-1070. [CrossRef]

47. Van Niel, G.; D’Angelo, G.; Raposo, G. Shedding Light on the Cell Biology of Extracellular Vesicles. Nat. Rev. Mol. Cell Biol. 2018, 19, 213-228. [CrossRef]

48. Li, B.; Antonyak, M.A.; Zhang, J.; Cerione, R.A. RhoA Triggers a Specific Signaling Pathway That Generates Transforming Microvesicles in Cancer Cells. Oncogene 2012, 31, 4740-4749. [CrossRef] [PubMed]

49. Muralidharan-Chari, V.; Clancy, J.; Plou, C.; Romao, M.; Chavrier, P.; Raposo, G.; D'Souza-Schorey, C. ARF6-Regulated Shedding of Tumor Cell-Derived Plasma Membrane Microvesicles. Curr. Biol. 2009, 19, 1875-1885. [CrossRef] [PubMed]

50. D'Souza-Schorey, C.; Chavrier, P. ARF Proteins: Roles in Membrane Traffic and Beyond. Nat. Rev. Mol. Cell Biol. 2006, 7, 347-358. [CrossRef] [PubMed]

51. Pellon-Cardenas, O.; Clancy, J.; Uwimpuhwe, H.; D'Souza-Schorey, C. ARF6-Regulated Endocytosis of Growth Factor Receptors Links Cadherin-Based Adhesion to Canonical Wnt Signaling in Epithelia. Mol. Cell. Biol. 2013, 33, 2963-2975. [CrossRef] [PubMed]

52. Schlienger, S.; Campbell, S.; Claing, A. ARF1 Regulates the Rho/MLC Pathway to Control EGF-Dependent Breast Cancer Cell Invasion. Mol. Biol. Cell 2014, 25, 17-29. [CrossRef] [PubMed]

53. Lee, T.H.; D'Asti, E.; Magnus, N.; Al-Nedawi, K.; Meehan, B.; Rak, J. Microvesicles as Mediators of Intercellular Communication in Cancer-the Emerging Science of Cellular "Debris". Semin. Immunopathol. 2011, 33, 455-467. [CrossRef]

54. Villarroya-Beltri, C.; Baixauli, F.; Gutiérrez-Vázquez, C.; Sánchez-Madrid, F.; Mittelbrunn, M. Sorting It out: Regulation of Exosome Loading. Semin. Cancer Biol. 2014, 28, 3-13. [CrossRef]

55. Mulcahy, L.A.; Pink, R.C.; Carter, D.R.F. Routes and Mechanisms of Extracellular Vesicle Uptake. J. Extracell. Vesicles 2014, 3. [CrossRef]

56. Bruno, S.; Grange, C.; Deregibus, M.C.; Calogero, R.A.; Saviozzi, S.; Collino, F.; Morando, L.; Busca, A.; Falda, M.; Bussolati, B.; et al. Mesenchymal Stem Cell-Derived Microvesicles Protect against Acute Tubular Injury. J. Am. Soc. Nephrol. 2009, 20, 1053-1067. [CrossRef] [PubMed]

57. Melo, S.A.; Luecke, L.B.; Kahlert, C.; Fernandez, A.F.; Gammon, S.T.; Kaye, J.; LeBleu, V.S.; Mittendorf, E.A.; Weitz, J.; Rahbari, N.; et al. Glypican-1 Identifies Cancer Exosomes and Detects Early Pancreatic Cancer. Nature 2015, 523, 177-182. [CrossRef]

58. Rana, S.; Yue, S.; Stadel, D.; Zöller, M. Toward Tailored Exosomes: The Exosomal Tetraspanin Web Contributes to Target Cell Selection. Int. J. Biochem. Cell Biol. 2012, 44, 1574-1584. [CrossRef]

59. Hoshino, A.; Costa-Silva, B.; Shen, T.-L.; Rodrigues, G.; Hashimoto, A.; Tesic Mark, M.; Molina, H.; Kohsaka, S.; Di Giannatale, A.; Ceder, S.; et al. Tumour Exosome Integrins Determine Organotropic Metastasis. Nature 2015, 527, 329-335. [CrossRef]

60. Barrès, C.; Blanc, L.; Bette-Bobillo, P.; André, S.; Mamoun, R.; Gabius, H.-J.; Vidal, M. Galectin-5 Is Bound onto the Surface of Rat Reticulocyte Exosomes and Modulates Vesicle Uptake by Macrophages. Blood 2010, 115, 696-705. [CrossRef]

61. Frey, B.; Gaipl, U.S. The Immune Functions of Phosphatidylserine in Membranes of Dying Cells and Microvesicles. Semin. Immunopathol. 2011, 33, 497-516. [CrossRef] [PubMed]

62. Purushothaman, A.; Bandari, S.K.; Liu, J.; Mobley, J.A.; Brown, E.E.; Sanderson, R.D. Fibronectin on the Surface of Myeloma Cell-Derived Exosomes Mediates Exosome-Cell Interactions. J. Biol. Chem. 2016, 291, 1652-1663. [CrossRef] [PubMed]

63. Leiss, M.; Beckmann, K.; Girós, A.; Costell, M.; Fässler, R. The Role of Integrin Binding Sites in Fibronectin Matrix Assembly in Vivo. Curr. Opin. Cell Biol. 2008, 20, 502-507. [CrossRef]

64. Ratajczak, J.; Miekus, K.; Kucia, M.; Zhang, J.; Reca, R.; Dvorak, P.; Ratajczak, M.Z. Embryonic Stem Cell-Derived Microvesicles Reprogram Hematopoietic Progenitors: Evidence for Horizontal Transfer of MRNA and Protein Delivery. Leukemia 2006, 20, 847-856. [CrossRef] [PubMed]

65. Deregibus, M.C.; Cantaluppi, V.; Calogero, R.; Lo Iacono, M.; Tetta, C.; Biancone, L.; Bruno, S.; Bussolati, B.; Camussi, G. Endothelial Progenitor Cell Derived Microvesicles Activate an Angiogenic Program in Endothelial Cells by a Horizontal Transfer of MRNA. Blood 2007, 110, 2440-2448. [CrossRef]

66. Penfornis, P.; Vallabhaneni, K.C.; Whitt, J.; Pochampally, R. Extracellular Vesicles as Carriers of MicroRNA, Proteins and Lipids in Tumor Microenvironment. Int. J. Cancer 2016, 138, 14-21. [CrossRef] 
67. Valadi, H.; Ekström, K.; Bossios, A.; Sjöstrand, M.; Lee, J.J.; Lötvall, J.O. Exosome-Mediated Transfer of MRNAs and MicroRNAs Is a Novel Mechanism of Genetic Exchange between Cells. Nat. Cell Biol. 2007, 9, 654-659. [CrossRef]

68. Skog, J.; Würdinger, T.; van Rijn, S.; Meijer, D.H.; Gainche, L.; Sena-Esteves, M.; Curry, W.T.; Carter, B.S.; Krichevsky, A.M.; Breakefield, X.O. Glioblastoma Microvesicles Transport RNA and Proteins That Promote Tumour Growth and Provide Diagnostic Biomarkers. Nat. Cell Biol. 2008, 10, 1470-1476. [CrossRef]

69. Collino, F.; Deregibus, M.C.; Bruno, S.; Sterpone, L.; Aghemo, G.; Viltono, L.; Tetta, C.; Camussi, G. Microvesicles Derived from Adult Human Bone Marrow and Tissue Specific Mesenchymal Stem Cells Shuttle Selected Pattern of MiRNAs. PLoS ONE 2010, 5, e11803. [CrossRef]

70. Ekström, K.; Valadi, H.; Sjöstrand, M.; Malmhäll, C.; Bossios, A.; Eldh, M.; Lötvall, J. Characterization of MRNA and MicroRNA in Human Mast Cell-Derived Exosomes and Their Transfer to Other Mast Cells and Blood CD34 Progenitor Cells. J. Extracell. Vesicles 2012, 1. [CrossRef]

71. Nolte-'t Hoen, E.N.M.; Buermans, H.P.J.; Waasdorp, M.; Stoorvogel, W.; Wauben, M.H.M.; 't Hoen, P.A.C. Deep Sequencing of RNA from Immune Cell-Derived Vesicles Uncovers the Selective Incorporation of Small Non-Coding RNA Biotypes with Potential Regulatory Functions. Nucleic Acids Res. 2012, 40, 9272-9285. [CrossRef] [PubMed]

72. Boon, R.A.; Vickers, K.C. Intercellular Transport of MicroRNAs. Arterioscler. Thromb. Vasc. Biol. 2013, 33, 186-192. [CrossRef] [PubMed]

73. Chiabotto, G.; Camussi, G.; Bruno, S. Role of NcRNAs in Modulation of Liver Fibrosis by Extracellular Vesicles. ExRNA 2020, 2, 7. [CrossRef]

74. Herrera, M.B.; Fonsato, V.; Gatti, S.; Deregibus, M.C.; Sordi, A.; Cantarella, D.; Calogero, R.; Bussolati, B.; Tetta, C.; Camussi, G. Human Liver Stem Cell-Derived Microvesicles Accelerate Hepatic Regeneration in Hepatectomized Rats. J. Cell. Mol. Med. 2010, 14, 1605-1618. [CrossRef] [PubMed]

75. Tan, C.Y.; Lai, R.C.; Wong, W.; Dan, Y.Y.; Lim, S.-K.; Ho, H.K. Mesenchymal Stem Cell-Derived Exosomes Promote Hepatic Regeneration in Drug-Induced Liver Injury Models. Stem Cell Res. Ther. 2014, 5, 76. [CrossRef]

76. Yan, Y.; Jiang, W.; Tan, Y.; Zou, S.; Zhang, H.; Mao, F.; Gong, A.; Qian, H.; Xu, W. HucMSC Exosome-Derived GPX1 Is Required for the Recovery of Hepatic Oxidant Injury. Mol. Ther. 2017, 25, 465-479. [CrossRef]

77. Jiang, W.; Tan, Y.; Cai, M.; Zhao, T.; Mao, F.; Zhang, X.; Xu, W.; Yan, Z.; Qian, H.; Yan, Y. Human Umbilical Cord MSC-Derived Exosomes Suppress the Development of CCl4-Induced Liver Injury through Antioxidant Effect. Stem. Cell. Int. 2018, 2018, 6079642. [CrossRef]

78. Haga, H.; Yan, I.K.; Borrelli, D.A.; Matsuda, A.; Parasramka, M.; Shukla, N.; Lee, D.D.; Patel, T. Extracellular Vesicles from Bone Marrow-Derived Mesenchymal Stem Cells Protect against Murine Hepatic Ischemia/Reperfusion Injury. Liver Transpl. 2017, 23, 791-803. [CrossRef]

79. Nong, K.; Wang, W.; Niu, X.; Hu, B.; Ma, C.; Bai, Y.; Wu, B.; Wang, Y.; Ai, K. Hepatoprotective Effect of Exosomes from Human-Induced Pluripotent Stem Cell-Derived Mesenchymal Stromal Cells against Hepatic Ischemia-Reperfusion Injury in Rats. Cytotherapy 2016, 18, 1548-1559. [CrossRef]

80. Du, Y.; Li, D.; Han, C.; Wu, H.; Xu, L.; Zhang, M.; Zhang, J.; Chen, X. Exosomes from Human-Induced Pluripotent Stem Cell-Derived Mesenchymal Stromal Cells (HiPSC-MSCs) Protect Liver against Hepatic Ischemia/ Reperfusion Injury via Activating Sphingosine Kinase and Sphingosine-1-Phosphate Signaling Pathway. Cell. Physiol. Biochem. 2017, 43, 611-625. [CrossRef]

81. Yao, J.; Zheng, J.; Cai, J.; Zeng, K.; Zhou, C.; Zhang, J.; Li, S.; Li, H.; Chen, L.; He, L.; et al. Extracellular Vesicles Derived from Human Umbilical Cord Mesenchymal Stem Cells Alleviate Rat Hepatic Ischemia-Reperfusion Injury by Suppressing Oxidative Stress and Neutrophil Inflammatory Response. FASEB J. 2019, 33, 1695-1710. [CrossRef]

82. Anger, F.; Camara, M.; Ellinger, E.; Germer, C.-T.; Schlegel, N.; Otto, C.; Klein, I. Human Mesenchymal Stromal Cell-Derived Extracellular Vesicles Improve Liver Regeneration After Ischemia Reperfusion Injury in Mice. Stem Cell. Dev. 2019, 28, 1451-1462. [CrossRef]

83. Haga, H.; Yan, I.K.; Takahashi, K.; Matsuda, A.; Patel, T. Extracellular Vesicles from Bone Marrow-Derived Mesenchymal Stem Cells Improve Survival from Lethal Hepatic Failure in Mice. Stem Cell. Transl. Med. 2017, 6, 1262-1272. [CrossRef] [PubMed]

84. Chen, L.; Xiang, B.; Wang, X.; Xiang, C. Exosomes Derived from Human Menstrual Blood-Derived Stem Cells Alleviate Fulminant Hepatic Failure. Stem Cell Res. Ther. 2017, 8, 9. [CrossRef] [PubMed] 
85. Jin, Y.; Wang, J.; Li, H.; Gao, S.; Shi, R.; Yang, D.; Wang, X.; Wang, X.; Zhu, L.; Wang, X.; et al. Extracellular Vesicles Secreted by Human Adipose-Derived Stem Cells (HASCs) Improve Survival Rate of Rats with Acute Liver Failure by Releasing LncRNA H19. EBioMedicine 2018, 34, 231-242. [CrossRef]

86. Tamura, R.; Uemoto, S.; Tabata, Y. Immunosuppressive Effect of Mesenchymal Stem Cell-Derived Exosomes on a Concanavalin A-Induced Liver Injury Model. Inflamm. Regen. 2016, 36, 26. [CrossRef] [PubMed]

87. Damania, A.; Jaiman, D.; Teotia, A.K.; Kumar, A. Mesenchymal Stromal Cell-Derived Exosome-Rich Fractionated Secretome Confers a Hepatoprotective Effect in Liver Injury. Stem Cell Res. Ther. 2018, 9, 31. [CrossRef]

88. Nojima, H.; Freeman, C.M.; Schuster, R.M.; Japtok, L.; Kleuser, B.; Edwards, M.J.; Gulbins, E.; Lentsch, A.B. Hepatocyte Exosomes Mediate Liver Repair and Regeneration via Sphingosine-1-Phosphate. J. Hepatol. 2016, 64, 60-68. [CrossRef] [PubMed]

89. Li, T.; Yan, Y.; Wang, B.; Qian, H.; Zhang, X.; Shen, L.; Wang, M.; Zhou, Y.; Zhu, W.; Li, W.; et al. Exosomes Derived from Human Umbilical Cord Mesenchymal Stem Cells Alleviate Liver Fibrosis. Stem Cells Dev. 2013, 22, 845-854. [CrossRef]

90. Qu, Y.; Zhang, Q.; Cai, X.; Li, F.; Ma, Z.; Xu, M.; Lu, L. Exosomes Derived from MiR-181-5p-Modified Adipose-Derived Mesenchymal Stem Cells Prevent Liver Fibrosis via Autophagy Activation. J. Cell. Mol. Med. 2017, 21, 2491-2502. [CrossRef]

91. Povero, D.; Pinatel, E.M.; Leszczynska, A.; Goyal, N.P.; Nishio, T.; Kim, J.; Kneiber, D.; de Araujo Horcel, L.; Eguchi, A.; Ordonez, P.M.; et al. Human Induced Pluripotent Stem Cell-Derived Extracellular Vesicles Reduce Hepatic Stellate Cell Activation and Liver Fibrosis. JCI Insight 2019, 5. [CrossRef] [PubMed]

92. Ohara, M.; Ohnishi, S.; Hosono, H.; Yamamoto, K.; Yuyama, K.; Nakamura, H.; Fu, Q.; Maehara, O.; Suda, G.; Sakamoto, N. Extracellular Vesicles from Amnion-Derived Mesenchymal Stem Cells Ameliorate Hepatic Inflammation and Fibrosis in Rats. Stem Cells Int. 2018, 2018, 3212643. [CrossRef] [PubMed]

93. Rong, X.; Liu, J.; Yao, X.; Jiang, T.; Wang, Y.; Xie, F. Human Bone Marrow Mesenchymal Stem Cells-Derived Exosomes Alleviate Liver Fibrosis through the Wnt/ $\beta$-Catenin Pathway. Stem Cell Res. Ther. 2019, 10, 98. [CrossRef] [PubMed]

94. Chen, L.; Chen, R.; Kemper, S.; Cong, M.; You, H.; Brigstock, D.R. Therapeutic Effects of Serum Extracellular Vesicles in Liver Fibrosis. J. Extracell. Vesicles 2018, 7, 1461505. [CrossRef]

95. Li, X.; Chen, R.; Kemper, S.; Brigstock, D.R. Extracellular Vesicles from Hepatocytes Are Therapeutic for Toxin-Mediated Fibrosis and Gene Expression in the Liver. Front. Cell Dev. Biol 2020, 7, 368. [CrossRef]

96. Mardpour, S.; Hassani, S.-N.; Mardpour, S.; Sayahpour, F.; Vosough, M.; Ai, J.; Aghdami, N.; Hamidieh, A.A.; Baharvand, H. Extracellular Vesicles Derived from Human Embryonic Stem Cell-MSCs Ameliorate Cirrhosis in Thioacetamide-Induced Chronic Liver Injury. J. Cell. Physiol. 2018, 233, 9330-9344. [CrossRef]

97. Mardpour, S.; Ghanian, M.H.; Sadeghi-Abandansari, H.; Mardpour, S.; Nazari, A.; Shekari, F.; Baharvand, H. Hydrogel-Mediated Sustained Systemic Delivery of Mesenchymal Stem Cell-Derived Extracellular Vesicles Improves Hepatic Regeneration in Chronic Liver Failure. ACS Appl Mater. Interfaces 2019, 11, 37421-37433. [CrossRef]

98. Fiore, E.; Domínguez, L.M.; Bayo, J.; Malvicini, M.; Atorrasagasti, C.; Rodriguez, M.; Cantero, M.J.; García, M.; Yannarelli, G.; Mazzolini, G. Human Umbilical Cord Perivascular Cells-Derived Extracellular Vesicles Mediate the Transfer of IGF-I to the Liver and Ameliorate Hepatic Fibrogenesis in Mice. Gene Ther. 2020, 27, 62-73. [CrossRef]

99. Chen, L.; Lu, F.-B.; Chen, D.-Z.; Wu, J.-L.; Hu, E.; Xu, L.-M.; Zheng, M.-H.; Li, H.; Huang, Y.; Jin, X.-Y.; et al. BMSCs-Derived MiR-223-Containing Exosomes Contribute to Liver Protection in Experimental Autoimmune Hepatitis. Mol. Immunol. 2018, 93, 38-46. [CrossRef]

100. Bruno, S.; Pasquino, C.; Herrera Sanchez, M.B.; Tapparo, M.; Figliolini, F.; Grange, C.; Chiabotto, G.; Cedrino, M.; Deregibus, M.C.; Tetta, C.; et al. HLSC-Derived Extracellular Vesicles Attenuate Liver Fibrosis and Inflammation in a Murine Model of Non-Alcoholic Steatohepatitis. Mol. Ther. 2020, 28, 479-489. [CrossRef]

101. Dong, L.; Pu, Y.; Chen, X.; Qi, X.; Zhang, L.; Xu, L.; Li, W.; Ma, Y.; Zhou, S.; Zhu, J.; et al. HUCMSC-Extracellular Vesicles Downregulated Hepatic Stellate Cell Activation and Reduced Liver Injury in S. Japonicum-Infected Mice. Stem Cell Res. Ther. 2020, 11, 21. [CrossRef]

102. Lou, G.; Yang, Y.; Liu, F.; Ye, B.; Chen, Z.; Zheng, M.; Liu, Y. MiR-122 Modification Enhances the Therapeutic Efficacy of Adipose Tissue-Derived Mesenchymal Stem Cells against Liver Fibrosis. J. Cell. Mol. Med. 2017, 21, 2963-2973. [CrossRef] 
103. Bari, E.; Perteghella, S.; Di Silvestre, D.; Sorlini, M.; Catenacci, L.; Sorrenti, M.; Marrubini, G.; Rossi, R.; Tripodo, G.; Mauri, P.; et al. Pilot Production of Mesenchymal Stem/Stromal Freeze-Dried Secretome for Cell-Free Regenerative Nanomedicine: A Validated GMP-Compliant Process. Cells 2018, 7, 190. [CrossRef] [PubMed]

104. Kordelas, L.; Rebmann, V.; Ludwig, A.K.; Radtke, S.; Ruesing, J.; Doeppner, T.R.; Epple, M.-; Horn, P.A.; Beelen, D.W.; Giebel, B. MSC-Derived Exosomes: A Novel Tool to Treat Therapy-Refractory Graft-Versus-Host Disease. Leukemia 2014, 28, 970-973. [CrossRef]

105. Bruno, S.; Collino, F.; Deregibus, M.C.; Grange, C.; Tetta, C.; Camussi, G. Microvesicles Derived from Human Bone Marrow Mesenchymal Stem Cells Inhibit Tumor Growth. Stem Cells Dev. 2013, 22, 758-771. [CrossRef] [PubMed]

106. Fonsato, V.; Collino, F.; Herrera, M.B.; Cavallari, C.; Deregibus, M.C.; Cisterna, B.; Bruno, S.; Romagnoli, R.; Salizzoni, M.; Tetta, C.; et al. Human Liver Stem Cell-Derived Microvesicles Inhibit Hepatoma Growth in SCID Mice by Delivering Antitumor MicroRNAs. Stem Cells 2012, 30, 1985-1998. [CrossRef] [PubMed]

107. Lopatina, T.; Bruno, S.; Tetta, C.; Kalinina, N.; Porta, M.; Camussi, G. Platelet-derived growth factor regulates the secretion of extracellular vesicles by adipose mesenchymal stem cells and enhances their angiogenic potential. Cell Commun. Signal. 2014, 12, 26. [CrossRef] [PubMed]

108. Kholia, S.; Herrera Sanchez, M.B.; Cedrino, M.; Papadimitriou, E.; Tapparo, M.; Deregibus, M.C.; Brizzi, M.F.; Tetta, C.; Camussi, G. Human Liver Stem Cell-Derived Extracellular Vesicles Prevent Aristolochic Acid-Induced Kidney Fibrosis. Front. Immunol. 2018, 9, 1639. [CrossRef]

109. Grange, C.; Tritta, S.; Tapparo, M.; Cedrino, M.; Tetta, C.; Camussi, G.; Brizzi, M.F. Stem Cell-Derived Extracellular Vesicles Inhibit and Revert Fibrosis Progression in a Mouse Model of Diabetic Nephropathy. Sci. Rep. 2019, 9, 4468. [CrossRef]

110. Kholia, S.; Herrera Sanchez, M.B.; Cedrino, M.; Papadimitriou, E.; Tapparo, M.; Deregibus, M.C.; Bruno, S.; Antico, F.; Brizzi, M.F.; Quesenberry, P.J.; et al. Mesenchymal Stem Cell Derived Extracellular Vesicles Ameliorate Kidney Injury in Aristolochic Acid Nephropathy. Front. Cell Dev. Biol. 2020, 8, 188. [CrossRef]

(C) 2020 by the authors. Licensee MDPI, Basel, Switzerland. This article is an open access article distributed under the terms and conditions of the Creative Commons Attribution (CC BY) license (http://creativecommons.org/licenses/by/4.0/). 